\title{
RISK MANAGEMENT AMONG MOUNTAIN BIKERS IN SELECTED CLUBS IN MALAYSIA
}

\author{
J. Zakaria
}

Faculty of Sports Science and Coaching, Universiti Pendidikan Sultan Idris, Tg Malim, Perak, Malaysia

Published online: 10 November 2017

\begin{abstract}
Mountain biking is the best pedal sport on road and off road trails. The element of adventure in this sport make many people like to join this challenging sports. This study examined the risk among mountain bikers in selected clubs in Malaysia. The main objective of this study is to reveal injuries among mountain bikers during their cycling session. All data in this study will be shown descriptively. Survey forms were distributed via active cycling clubs in Perak states. The respondents need to testify their previous injuries during their previous activities. The data shows the age of the mountain bikers, their experiences and abilities. From a total of 225, only 192 repondents experienced and had an injury during the activities. The result showed only $43.2 \%$ seeked medical attention and went to the hospital or clinic after experiencing an injury. Mountain biking activities require the cyclist to be physically and mentally fit and the equipment, which is the bike itself. Best practice and proper skill trainingshelp them to avoid accident during the activities. The new discipline called 'down hill' is getting more popular and can be one of the future studies because this new discipline is more risky.
\end{abstract}

Keywords: mountain biking, risk management, event management, Malaysia

Author Correspondence, e-mail: jaffry@fsskj.upsi.edu.my

doi: http://dx.doi.org/10.4314/jfas.v9i6s.101 


\section{INTRODUCTION}

Mountain biking has been established as a fast, exciting adventure sport that is promptly developing. Today, the mountain bike is the most popular type of bicycle to ride and off road cycling as a recreational activity is currently very popular. Competitive mountain biking is also progressively very popular [1]. Mountain biking was awarded full Olympic status at the 2000 games in Sydney.Mountain biking is a very adventurous and challenging activity which offers emotional, physical and social benefits to those who participate in this activity. This activity can be beneficial to prevent diseases, keeps your heart healthy, redeuces stress, makes you happy, offers a temporary escape from daily work commitments and also helps in gathering of friends. Mountain biking is not only an adventure activity but it also helps a person to stay fit. Biking just two to three hours a week can improve your lung capacity by up to 20 percent [2]. Wearing a proper attire and safety equipment such as helmet, knee guard, elbow guard, shoes with socks and also glove is most important. The bikers should know basic technique to be able to ride in safe and correct position.

The present study aims to study the risk management and identify the types of injuries often experienced by mountain bikers in Malaysia. With the identification of these injuries, the risks could also be identified and a proper risks management among the mountain bikers could be established.

\section{RESULTS AND DISCUSSION}

Data were collected from 225 mountain bikers. Out of this, only 192 respondents experienced injuries during the activity. The rest of the respondent did not suffer any injuries while they were cycling. Based from the study, most mouatain bikers were injured when they were in the Proton City Trail (30\%), Thompson Trail (24\%), Teratak Trail (19\%), Ulu Bernam Trail (13\%) and Gedangsa Trail (14\%). Table 1 shows the injuries by area. 
Table 1. Injuries by trail

\begin{tabular}{ccc}
\hline No. & Injuries by trail & Total Results (\%) \\
\hline 1. & Proton City Trail & $30 \%$ \\
2. & Thompson Trail & $24 \%$ \\
3. & Teratak Trail & $19 \%$ \\
4. & Ulu Bernam Trail & $13 \%$ \\
5. & Gedangsa Trail & $14 \%$ \\
\hline
\end{tabular}

The risk management process is most important to the mountain bikers. They should know the trail before they start a ride. Table 2 shows injuries by location among mountain bikers. The most difficult area where injuries often occurred are down hill (33\%) followed by rock garden (26\%), chicken loop (24\%) and single trail 17\%.

Table 2. Injuries by location

\begin{tabular}{ccc}
\hline No. & Injuries by location & Total Results (\%) \\
\hline 1. & Down hill & $33 \%$ \\
2. & Rock garden & $26 \%$ \\
3. & Chicken loop & $24 \%$ \\
4. & Single trail & $17 \%$ \\
\hline
\end{tabular}

Table 3 shows the type of injuries among mountain bikers. The most common types of injuries are dislocation (31\%), sprain (27\%), tendinitis $(22 \%)$, fracture $(10 \%)$ and blister (10\%). 
Table 3. Type of injuries

\begin{tabular}{ccc}
\hline No. & Types of injuries & Total Results (\%) \\
\hline 1. & Dislocation & $31 \%$ \\
2. & Sprain & $27 \%$ \\
3. & Tendinitis & $22 \%$ \\
4. & Fracture & $10 \%$ \\
5. & Blister & $10 \%$ \\
\hline
\end{tabular}

A multistep process is required to prevent injuries in sports [3]. First, informations about the injury extent and aetiology in a particular sport are gathered. Next, risk factors and potential remedies are identified followed by the introduction of reventive measures, which then need to be evaluated [4].

In particular, mountain biking has been the subject of increasing media attention due to several severe injuries among its athletes. However, little is known about the rik of injury involved in participation. Severe injuries including dislocation and fracture of the cervical spine and a case of incomplete tetraplegia was reported by Jeys et al. [5] andApsingi et al. [6]. A fall onto the top of the head could result in a flexion injury, whereas a fall onto the face could results in hyperextension [7]. The cervical spine is the commonest site of spinal injury [8]. A report by Kelly [9] showed that $13 \%$ of sport- related head injuries presenting to an emerrgeny department were sustained while cycling. However, in McDermott's study of 1710 bicycling injuries, helmet use has reduced the risk of head injuries by $39 \%$ and the risk of facial injury by $28 \%$ [10]. The importance of head protection has been appreciated with the majority of off mountain bike cyclists wearing helmets [5]. According to Carmont, most serious injuries to the head and neck occur whilst falling over the handlebars rather than falling off the bike to the side, which tends to result in the lower limbs injuries. As a consequence of this, female bikers who are lighter and as a result fall over the handlebars easier than male, tend to be seriouslt injured than male riders. However most injuries sustained mountain biking occur to young males aged 20-39 years [1]. 


\section{EXPERIMENTAL}

This study was done starting in March 2011 and ended in July 2017. The respondents are mountain bikers in different clubs in Perak state of Malaysia.The response were given either through online survey or via face to face. At the beginning of the survey, every athlete was asked to complete information rearding their name, age, gender, height,weight, experiences in mountain biking in years, level of performance, previous injuries and safety equiments. The questionnaires were distributed via active mountain bikers club. All the clubs are active in organizing trips and events in their areas. According to the suveys received, most of the respondents did the survey via online research. This study only analyses the result from mountain bikers at the selected areas only. All data was analyzed statistically using SPSS version 20 .

\section{CONCLUSION}

In conclusion, from the injuries reported in this study, mountain bikers should be well trained, ride within their level of capability, use a well-maintained bike without handlebar ends and must learn to dismount safely. They should also wear helmets with facial protection, padded gloves and shorts. In addition, cushioned seats and shin protection must be taken into serious consideration too. Mountain biking is an exciting and fast adventure sport that may lead to serious injury. However, the majorities of injuries are minor and can be minimized with care and preacautions.

\section{ACKNOWLEDGEMENTS}

The author would like to thank Universiti Pendidikan Sultan Idris, Tg. Malim, Perak, Malaysia and Faculty of Sport Science and Coaching for providing full support throughout the progress and completion of this research.

\section{REFERENCES}

[1] Carmont M.R., British Medical Bulletin. 2008, 85, 101-112, doi: 10.1093/bmb/1dn009. Articles without DOIs

[2] Adams S. and Martin F.. "Mountain Biking the Washington D.C./Baltimore 
Area".Guilford:Falcon, 2003.

[3] van Mechelen W., Hlobil H. and Kemper H.C. Incidence, severity, aetiology and prevention of sports injuries.A review of concepts. Sports Med., 1992, 14: 82-99.

[4] Moroder P., Runner A., Hoffelner, T. A prospective study of kitesurfing injuries.Am. J. Sports Med., 2011. 39: 1534-1540.

[5] Jeys L.M., Cribb, G. and Toms A.D. Mountain biking injuries in rural England.Br. J. Sports Med., 2001. 35:197-199.

[6] Apsingi, S., Dussa C.U., Soni B.M. Acure cervical spine injuries in mountain biking: a report of 3 cases. Am. J. Sports Med, 2006. 34: 487-489.

[7] Allen B.L. Jr., Ferguson R.L., Lehmann, T.R. and O’Brien R.P. A mechanistic classification of closed, indirect fractures and dislocations of the lower cervical spine.Spine., 1982. 7:1-27.

[8] Kim P.T.W., Janga D. and Ritchie A.H. Mountain biking injury requiring trauma centre admission. J. Trauma, 2006. 60: 312-318.

[9] Kelly K.D., Lissel H.L. and Rowe B.H. Sport and recreation related head injuries treated in the emergency department. Clin J. Sports Med., 2001. 11:77-81.

[10] McDermott F.T. (1993). The effectiveness of bicyclist's helmets: a study of 1710 casualties. J. Trauma.,1993. 34: 834-845.

\section{How to cite this article:}

Zakaria J. Risk management among mountain bikers in selected clubs in Malaysia. J. Fundam. Appl. Sci., 2017, 9(6S), 1372-1377. 